\title{
Effects of burrowing mud lobsters (Thalassina anomala Herbst 1804) on soil macro- and micronutrients in a Malaysian mangrove
}

\begin{abstract}
The mud lobster, genus Thalassina is the least studied taxon compared to other mud crabs within Thalassinidae family. Burrowing thalassinid populations are considered to be an effective means of bioturbation, affecting the macro- and micronutrient properties in the substrates they occur in through nutrient redistribution. This study assessed the combined effects of fresh mud excavation and old mud deposition on soil turnover and vertical marconutrients including $\mathrm{NH}_{4}-\mathrm{N}, \mathrm{NO}_{3}-\mathrm{N}, \mathrm{P}, \mathrm{K}, \mathrm{S}, \mathrm{Na}, \mathrm{Ca}$, and $\mathrm{Mg}$ and micronutrients including $\mathrm{Fe}, \mathrm{Cu}, \mathrm{Zn}$ and $\mathrm{Mn}$ distributions in a Malaysian mangrove, Sibuti Wildlife Sanctuary, Sarawak. The mud lobster Thalassina anomala (Decapoda: Thalassinidae) inhabits and builds mounds both seafront and inland mangroves. Their burrowing activities increased $\mathrm{NH}_{4}-\mathrm{N}$, $\mathrm{NO}_{3}-\mathrm{N}, \mathrm{P}$, and $\mathrm{Na}$ concentrations in fresh mud and $\mathrm{Fe}, \mathrm{Cu}$ and $\mathrm{Zn}$ concentrations in the old mud. The nutrient concentrations in excavated soils were greatly affected by habitat type, and depth. Burrowing processes can effectively turnover subsurface soil to the surface, which acidifies strongly upon oxidation. Higher $\mathrm{S}$ content in mud lobster soil together with low $\mathrm{pH}$ revealed mud lobsters play a strong role in the development of acidity in the study areas. These processes could stimulate formation of acid sulphate soil in the mangroves. Therefore, bioturbation not only affects soil physical and chemical properties but also ecological functions of mangroves, and needs proper attention during restoration and reclamation programs of mangrove forests.
\end{abstract}

Keyword: Mud lobster; Soil nutrient; Bioturbation; South China Sea; Mangrove 